\title{
THE SECTORALANALYSE OF ROLE CONFLICT AND ROLE AMBIGUITY WITH JOB SATISFACTION AND ORGANIZATIONAL COMMITMENT: A STUDY IN THE EAST MEDITERRANEAN REGION
}

\author{
M. Turan ÇUHADAR \\ Dr., Deputy Governor, Ordu, Turkey
}

\begin{abstract}
The main object of this paper is to analyse the sectoral perception and difference of role conflict and role ambiguity with job satisfaction and organizational commitment. This study was conducted with employees from both public and private sector firms in the Mediterranean Region of Turkey. The data gathered from 219 employees was analyzed to test the three hypotheses of the study.

Findings indicated that role conflict, role ambiguity, job satisfaction and organizational commitment are different to in public and private sector. This study concluded that managers must reduce the level of role conflict and role ambiguity if they want to increase job satisfaction and organizational commitment. As a result, organizational performance and effectiveness could be further improved. In addition, this study recommends that similar research be conducted on various employee groups to expand the antecedents and outcomes of role conflict and role ambiguity.
\end{abstract}

Key Words: Role conflict, role ambiguity, organizational commitment, job satisfaction.

\section{INTRODUCTION}

Employee job satisfaction and organizational commitment are two important criteria of organizational performance. The basic means of the concept of economic reconstruction, mainly cooperative strategies (e.g. alliances, business networks, joint ventures) and privatization, which started in the early 1980 s, resulted mass dismissals, have affected employees' level of job satisfaction and organizational commitment in a negative way. After 1980's, particularly collapsing the east bloc countries, as well as those countries and in Turkey, privatization has been the most important issue in the state economic policy. Programs intended to increase employees' organizational effectiveness have caused ambiguity about the work they do. Consequently, this ambiguity led to stress. One of the approaches explaining the stress of an employee is the role theory. According to the role theory, responsibilities of all employees and positions at work should be defined. Only under these circumstances, managers can direct employees; and, in turn, employees can report on their work and responsibilities. If employees are unclear how much authority they have and what is expected from them, they will refrain from decisions making and exhibiting behaviours that are relevant to the organization's aims (Jackson and Schuler, 1985). On the other hand, clearly defined job roles can strengthen employees' feelings related to the efficiency of their abilities. In this case, employees know what is to be done and what is expected from him or her.

Explanations about employees' roles and responsibilities are not always clear. The content in which the authority is determining the role and the person who undertakes this role is constantly changing (Schaubroeck et al., 1993). Several factors can cause ambiguity including the problems arising from determining and defining the process of the role; the limitations that emerge from the nature of the job and the organization; the differences in management forms and conflicts amongst the roles of the employees. Two employee behaviours that are affected by role conflict and ambiguity are job satisfaction and organizational 
commitment. Within this context, the aim of this study is to reveal sectoral difference or similarity in role ambiguity, role conflict, job satisfaction and organizational commitment in private and state sector.

This study aims to contribute to existing research on what the similarity and differences role ambiguity and role conflict affect job satisfaction and organizational commitment in public and private sector. Studies related to the topic in Turkish management are very rare, and this study should be regarded as an appendix to these studies in the numerical context. On the other hand, as Babin and Boles (1998) point out that the understanding about the role conflict and ambiguity can be deepened via empirical studies, which can be conducted on different cultural and job groups. Moreover, this study will contribute to projects developed to increase job satisfaction and organizational commitment when taken into account by the human resource management staff.

\section{LITERATURE REVIEW}

Role Conflict and Ambiguity Scale (Rizzo et al., 1970) and the Job Satisfaction Scale (Warr et al., 1979) were used to measure job satisfaction, role conflict and role ambiguity in both Redfern et al.'s (2002) study and Draper et al.'s (2004) study. Kahn et al. (1964) and Katz and Kahn (1978) defined role conflict as the simultaneous occurrence of two or more sets of pressures such that compliance with one would make compliance with the other more difficult. Building on Kahn et al. (1964), Rizzo et al. (1970) defined role conflict in terms of the compatibility of demands on the individual; the incompatibility may be due to conflicts between organizational demands and one's own values, problems of personal resource allocation, or conflicts between obligations to several different people. Greene (1978), Kemery et al. (1987), and Miles (1976) have all adopted the Rizzo et al. conceptualization ("incongruities arising out of perceptions of role requirements") in their respective studies.

The Organizational Commitment Scale (Mowday et al., 1979) was adopted by AL-Aameri (2000) and Redfern et al. (2002) to measure organizational commitment in their studies. These three scales were reported to have good reliability and validity in all these studies. Thus they are the measures of choice in the present study.

According to the results of a meta-analytical study conducted by Brown and Peterson (1993), and in many empirical studies, it is evident that role conflict and role ambiguity affect employee job satisfaction in a negative way (Babakus et al., 1996 and 1999; Grant et al., 2001; Weatherly and Tansik, 1993). A positive relationship between job satisfaction and organizational commitment has been reported by studies which involve qualified professionals. Redfern et al. (2002) reported a strong positive relationship between job satisfaction and organizational commitment.

Job stress, stemmed from both role conflict and role ambiguity is the main topic of many research studies (Keenan and McBain, 1979; Jamal, 1990; Babakus et al., 1996). Yousef (2000) conducted one of these studies, observing that role conflict and role ambiguity together do not effect job satisfaction and employee reactions to organizational change. Role conflict and role ambiguity do, however, affect job satisfaction when they are considered separately.

Harris et al. (2006) found that role conflict and role ambiguity affect employees' level of resourcefulness in a negative way. The level of resourcefulness of role conflict and role ambiguity that is affected negatively influences job satisfaction and employee intention to leave. This particular study showed that the job satisfaction level of employees who have a low resourcefulness level is lower than those who have high levels.

Lankau et al. (2006) conducted a study that dealt with increasing resourcefulness and role conflict and role ambiguity together. In this study, the authors looked at whether or not role conflict and role ambiguity effect the mentor's job satisfaction and organizational commitment. The findings showed that through mentoring, employees role conflict and role ambiguity levels of are reduced. Thus, the job satisfaction and organizational commitment are increased.

Namasivayam and Xinyuan (2006) studied the effect of job and family conflict on job satisfaction and organizational commitment using data gathered from hotel staff. Using hierarchic regression analysis method, the authors observed that family-related roles and jobrelated roles are often in conflict. This conflict affects an individual's job satisfaction in a negative way. When the relationship between job satisfaction and organizational commitment are studied, it was observed that a strong relationship exists between emotional organizational commitment and job satisfaction; on the other hand, the relationship between the ruledominant organizational commitment and job satisfaction is weaker. Organizational commitment in terms of continuity has not been observed to have any effect on job satisfaction. 


\section{STUDY HYPOTHESES}

This study looks at the sectoral similarity or differences of role conflict, role ambiguity, job satisfaction and organizational commitment. Three hypotheses connected with the aim are developed and tested:

Hypothesis 1: On the employee of the private and the public sectors, role conflict and role ambiguity show some differences between the sectors.

Hypothesis 2: On the employee of the private and the public sectors, organizational commitment shows some differences between the sectors.

Hypothesis 3: On the employee of the private and the public sectors, job satisfaction shows some differences between the sectors.

\section{METHODOLOGY}

\section{Sampling and Data}

The data for this study was obtained from employees of two public organizations (stands for $\mathrm{O}$ and $\mathrm{S}$ ) in the East Mediterranean Region included Adana, Mersin, Osmaniye, and Hatay provinces and two private firms (stands for $\mathrm{T}$ and $\mathrm{C}$ ) operating in the city of Adana, one of them is selling the products all over the world, 2008 in Turkey. Convenience sampling method was used. Questionnaires were prepared to measure role conflict with the role ambiguity and job satisfaction surveys were given to volunteers who were willing to help in the study. They were asked to have as many employees as possible fill in the forms and then return them within one week. In total, 257 surveys were distributed to four institutions, with 219 assessed as "eligible." Public sector employees accounted for $67.6 \%$ of the sample, with public sector employee account for $32.4 \%$ of the sample. Men accounted for $85.2 \%$ of the volunteers and $14.8 \%$ were women.

The oldest age group of volunteers was $36-40$ with a percentage of $18.3 \%$. The lowest age group of participants is $46-50$, with a percentage of $13.4 \%$. The majority are university graduates at $69.9 \%$. The percentage of the undergraduates is $13.4 \%$, while masters' degree and doctorate degree students amounted to $16.1 \%$. The percentage of the people who worked for the same institution for five or less years is $24.7 \%$ and this is the greatest group. On the other hand, those who worked in the same institution for 11-15 years are the smallest group with a percentage of $8.25 \%$.

\section{Variables}

Role conflict developed by Rizzo et al. (1970) is the first scale developed to measure role conflict. The scale consisting of eight items, participants' answers were obtained according to Likert measurement scale ( 1 = I don't agree at all, $7=$ I completely agree $).$ In the scale, sample items are: "Sometimes, I am under the necessity of doing my work", "Sometimes I am requested to do something by my superior that includes missing information" and "I work without getting enough personnel support" (appendix-1). The reliability of role conflict varies between .71 and .87 .

The scale reliability obtained in this study is .77 . The average of these eight items, forming role conflict is used to constitute a single role conflict variable. Yet, the role ambiguity scale developed by Rizzo et al. (1970) consists of six items. In some of the items used to measure role ambiguity, there are such explanations like "I always understand the things I am asked very well;" "I am sure that I manage my time right;" and "I am completely aware of the responsibilities about my job." The items of the role ambiguity scale are obtained according to the Likert scale, but they were encoded reversely $(1=\mathrm{I}$ do not agree at all, $7=\mathrm{I}$ completely agree). The reliability of this scale varies between .71 and .95 compared to previous studies. The scale reliability measured for this study is .69 . After making the reverse encoding of these six items constituting role ambiguity, the average value of these articles was used to obtain a single role ambiguity variable.

There are seven items in the job satisfaction scale, developed by Taylor and Bowers (1974). The scale aims to measure job satisfaction according to the work the individual does, his or her colleagues, managers, promotion opportunities and organization. The reliability parameter values are varying between .61 and .71 . The scale reliability measured for this study is .76. The average value of the seven items constituting job satisfaction was used to form a single job satisfaction variable.

The Organizational Commitment was origianally developed by Mowday, Steers, and Porter (1979). It uses 15 items to describe global organizational commitment. In this study the shortened organizational commitment questionnaire was used. Coefficient alpha values ranged from .74 to .92 (Aryee, Luk, and Stone 1998; Cohen, 1995, 1996; Dulebohn and Martocchio, 1998; Huselid and Day, 1991; Jones, Scarpello, and Bergmann, 1999; Kirchmeyer, 1992; Mathieu and Farr, 1991; Somers and Casal, 1994; Thompson and Werner, 1997; Wahn, 1998; Wayne, Shore, and Liden, 1997). The scale reliability measured for this study is .88. There are nine questions were asked to participants to measure organizational commitment, and answers 
of the participants were evaluated based on total score. Total score of at least 9 and at most 63 can be taken. Increase of scores obtained indicates that organizational dependence is high for this dimension.

\section{Data Analysis}

We benefited from descriptive, one way ANOVA, regression and correlation statistical techniques for data analysis. Frequencies and percentages were used to explain the age, gender, education, experience, and the other basic qualities of exemplification. Likewise, the correlation co-efficient, standard deviation, and the averages of the variables were measured. Multiregression method was used to understand the effect of role conflict and role ambiguity on job satisfaction and organizational commitment. This multi-regression method enables us to explain uncommitted and committed variable relationships not only as exemplification, but also as the relationships and interaction among variables in the population where the sample is drawn (Churchill, 1999).

\section{FINDINGS}

Table 1 shows the basic statistical values according to the variables used in the study. The role conflict and the role ambiguity averages of employees constituting the sample are respectively 4.21 and 2.46 . In other words, the role conflict that employees perceive is at a medium level, with role ambiguity more intensive. From the point of view of job satisfaction, the medium level value points out that employee are satisfied with their jobs. The 5.52 average signifies that the organizational commitment of sample is strong.

Table 1: The Basic Statistics Belonging to Study Variables.

\begin{tabular}{|l|r|r|r|r|r|}
\hline Variable & $\begin{array}{r}\text { Number of } \\
\text { Questions }\end{array}$ & Interspace & $\begin{array}{r}\text { Arithmetic } \\
\text { Mean }\end{array}$ & Median & $\begin{array}{r}\text { Standard } \\
\text { Deviation }\end{array}$ \\
\hline $\begin{array}{l}\text { Role } \\
\text { Conflict }\end{array}$ & 8 & 6 & 4.21 & 4.13 & 1.23 \\
\hline $\begin{array}{l}\text { Role } \\
\text { Ambiguity }\end{array}$ & 6 & 5 & 2.46 & 2.50 & .94 \\
\hline $\begin{array}{l}\text { Job } \\
\text { Satisfaction }\end{array}$ & 7 & 6 & 5.02 & 5.29 & 1.18 \\
\hline $\begin{array}{l}\text { Organizational } \\
\text { Commitment }\end{array}$ & 9 & 5.33 & 5.52 & 5.78 & 1.13 \\
\hline
\end{tabular}

In this section, the hypothesis will be tested and explained, respectively. Moreover, some statistical method such as descriptive analysis, one way ANOVA and multiple comparisons are used respectively.
Table 2: role conflict and role ambiguity on the public and the private sectors

\begin{tabular}{|r|r|r|r|r|}
\hline & & N & Mean & $\begin{array}{r}\text { Std. } \\
\text { Deviation }\end{array}$ \\
\hline Role conflict and role ambiguity & O & 45 & 4,8143 &, 72226 \\
\hline & S & 86 & 4,8189 &, 83290 \\
\hline & T & 36 & 4,5933 &, 63952 \\
\hline & C & 29 & 4,1798 &, 60507 \\
\hline & Total & 196 & 4,6819 &, 77288 \\
\hline
\end{tabular}

As it is seen in Table 2, role conflict and role ambiguity differs between public foundations and private sector corporations. According to Table 2, while the mean of O personnel is 4,8143, S personnel is 4,8189 in public foundations, the descriptive mean of $\mathrm{T}$ is 4,5933 and $\mathrm{C}$ is 4,1789 in private sector corporations. According to this table, the mean rate from the highest to the lowest is $\mathrm{S}>\mathrm{O}>\mathrm{T}>\mathrm{C}$; so, the biggest difference is between $\mathrm{S}$ and $\mathrm{C}$ and the private sector corporations has a mean under the total mean rate which is 4,6819 .

Table 3: one way ANOVA statistical results of role conflict and role ambiguity

\begin{tabular}{|l|l|r|r|r|r|r|}
\hline & & $\begin{array}{r}\text { Sum of } \\
\text { Squares }\end{array}$ & df & $\begin{array}{r}\text { Mean } \\
\text { Square }\end{array}$ & F & Sig. \\
\hline $\begin{array}{l}\text { Role conflict and } \\
\text { role ambiguity }\end{array}$ & $\begin{array}{l}\text { Between } \\
\text { Groups }\end{array}$ & 9,998 & 3 & 3,333 & 6,009 &, 001 \\
\hline & $\begin{array}{l}\text { Within } \\
\text { Groups }\end{array}$ & 106,485 & 192 &, 555 & & \\
\hline & Total & 116,483 & 195 & & & \\
\hline
\end{tabular}

Table 4: multiple comparisons method result of role conflict and role ambiguity

\begin{tabular}{|l|r|r|r|r|}
\hline $\begin{array}{l}\text { Dependent } \\
\text { Variable }\end{array}$ & $\begin{array}{r}\text { (I)surveyed } \\
\text { institution }\end{array}$ & $\begin{array}{r}\text { (J)surveyed } \\
\text { institution }\end{array}$ & $\begin{array}{r}\text { Mean } \\
\text { Difference (I-J) }\end{array}$ & Sig. \\
\hline $\begin{array}{l}\text { Role conflict } \\
\text { and ambiguity }\end{array}$ & $\mathrm{O}$ & $\mathrm{S}$ &,- 00465 & 1,000 \\
\hline & & $\mathrm{T}$ &, 22103 &, 624 \\
\hline & & $\mathrm{C}$ &, $63448\left(^{*}\right)$ &, 006 \\
\hline & $\mathrm{S}$ & $\mathrm{O}$ &, 00465 & 1,000 \\
\hline & & $\mathrm{T}$ &, 22568 &, 508 \\
\hline & & $\mathrm{C}$ &, $63913\left(^{*}\right)$ &, 002 \\
\hline & $\mathrm{T}$ & $\mathrm{O}$ &,- 22103 &, 624 \\
\hline & & $\mathrm{S}$ &,- 22568 &, 508 \\
\hline & & $\mathrm{C}$ &, 41345 &, 179 \\
\hline & $\mathrm{C}$ & $\mathrm{O}$ &,$- 63448\left(^{*}\right)$ &, 006 \\
\hline & & $\mathrm{S}$ &,$- 63913\left(^{*}\right)$ &, 002 \\
\hline & & $\mathrm{T}$ &,- 41345 &, 179 \\
\hline
\end{tabular}

* The mean difference is significant at the .05 level.

The one way analysis that is done to measure the H1 hypothesis also proves the accuracy of the hypothesis. As it is understood from Table 3 above, in the mean square at 0,05 ,role conflict and role ambiguity differs between public and private sector corporations. 
Because, the significance rate for role conflict and role ambiguity is lower than 0,05 .So, our hypothesis which is developed at 0,05 mean square, is accepted, too.

Multiple comparison analysis is aimed to identificate that in which public and private sector corporations, role conflict and role ambiguity is different. In the 0,05 mean square, it is identified that role conflict and role ambiguity differs between $\mathrm{O}$ and $\mathrm{C}$. It is understood that public and private sector corporations in Table 4 whose sig. rates are lower than 0,05 , are also different. According to multiple comparison analysis, the sig. rate between $\mathrm{O}$, which is a public foundation, and $\mathrm{C}$, which is a private sector corporation, is $\mathrm{P}=0$ and $006<0,05$;sig. rate between $\mathrm{S}$ and $\mathrm{C}$ is $\mathrm{P}=0,002<0,005$; the difference between $\mathrm{C}$, which is a private sector corporation, and $\mathrm{O}$, which is a public foundation, $\mathrm{O}, 006$ and $\mathrm{S}, 002$ is accepted reasonable. So, our hypothesis that is developed at 0,05 mean square is accepted, too.

Table 5: Organizational commitment on the public and the private sectors

\begin{tabular}{|l|r|r|rr|}
\hline & & $\mathrm{N}$ & Mean & $\begin{array}{r}\text { Std. } \\
\text { Deviation }\end{array}$ \\
\hline $\begin{array}{l}\text { Organizational } \\
\text { Commitment }\end{array}$ & $\mathrm{O}$ & 49 & 5,8730 &, 94933 \\
\hline & $\mathrm{S}$ & 95 & 5,1778 & 1,28308 \\
\hline & $\mathrm{T}$ & 37 & 5,7538 &, 74311 \\
\hline & $\mathrm{C}$ & 28 & 5,8016 & 1,00313 \\
\hline & Total & 209 & 5,5263 & 1,13198 \\
\hline
\end{tabular}

As it is seen in Table 5, organizational commitment does not show an obvious and clear difference in terms of public and private sector corporation's descriptive statistics. According to Table 5, there is 5,1778 descriptive mean among the personnels of $S$, which is a public foundation. According to this situation, the rate of $\mathrm{S}$ is the further rate to the mean rate which is 5,5263 . So, there is not a reasonable difference between $\mathrm{S}$ and other private sector corporations.

Table 6: one way anova statistical results of organizational commitment

\begin{tabular}{|l|r|r|r|r|r|r|}
\hline & & $\begin{array}{c}\text { Sum of } \\
\text { Squares }\end{array}$ & df & $\begin{array}{c}\text { Mean } \\
\text { Square }\end{array}$ & F & Sig. \\
\hline $\begin{array}{l}\text { Organizational } \\
\text { Commitment }\end{array}$ & $\begin{array}{r}\text { Between } \\
\text { Groups }\end{array}$ & 21,466 & 3 & 7,155 & 5,986 &, 001 \\
\hline & Within & & 245,059 & 205 & 1,195 & \\
\hline & Groups & & & & & \\
\hline & Total & 266,525 & 208 & & & \\
\hline
\end{tabular}

The one way analysis that is done to measure the $\mathrm{H} 2$ hypothesis also proves the accuracy of the hypothesis as seen in Table 6.As it is actually understood from the table above, at 0,05 mean square, organizational commitment differs according to public and private sector corporations. Because, organizational commitment sig. rates in Table 6 are lower than 0,05 . So, our hypothesis which is developed at, $001<0,05$ mean square is accepted, too.

Table 7: multiple comparision method result of organizational commitment

\begin{tabular}{|l|rr|r|c|}
\hline $\begin{array}{l}\text { Dependent } \\
\text { Variable }\end{array}$ & $\begin{array}{r}\text { (I)surveyed } \\
\text { institution }\end{array}$ & $\begin{array}{r}\text { (J)surveyed } \\
\text { institution }\end{array}$ & $\begin{array}{r}\text { Mean } \\
\text { Difference (I-J) }\end{array}$ & Sig. \\
\hline $\begin{array}{l}\text { Organizational } \\
\text { Commitment }\end{array}$ & $\mathrm{O}$ & $\mathrm{S}$ & $\mathbf{6 9 5 2 4}\left(^{*}\right)$ &, $\mathbf{0 0 5}$ \\
\hline & & $\mathrm{T}$ &, 11926 &, 969 \\
\hline & $\mathrm{C}$ &, 07143 &, 995 \\
\hline & $\mathrm{S}$ & $\mathrm{O}$ & $\mathbf{- , 6 9 5 2 4}\left(^{*}\right)$ &, $\mathbf{0 0 5}$ \\
\hline & & $\mathrm{T}$ &,- 57598 &, 064 \\
\hline & $\mathrm{T}$ & $\mathrm{C}$ &,- 62381 &, 074 \\
\hline & & $\mathrm{O}$ &,- 11926 &, 969 \\
\hline & & $\mathrm{S}$ &, 57598 &, 064 \\
\hline & $\mathrm{C}$ & $\mathrm{O}$ &,- 04783 &, 999 \\
\hline & & $\mathrm{S}$ &, 62381 &, 074 \\
\hline & & $\mathrm{T}$ &, 04783 &, 999 \\
\hline
\end{tabular}

* The mean difference is significant at the .05 level.

Multiple comparison analysis is aimed to identificate that in which public and private sector corporations, organizational commitment is different. As it is understood from Table 7, it is identified that organizational commitment differs between $\mathrm{O}$ and $\mathrm{S}$ at 0,05 mean square. Both of these are public foundations.

Table 8: job satisfaction on the public and the private sectors

\begin{tabular}{|r|r|r|r|r|}
\hline & & N & Mean & $\begin{array}{r}\text { Std. } \\
\text { Deviation }\end{array}$ \\
\hline Job Satisfaction & O & 46 & 5,4099 &, 85535 \\
\hline & S & 94 & 4,5653 & 1,27344 \\
\hline & T & 39 & 5,2601 & 1,07399 \\
\hline & C & 29 & 5,5172 &, 91187 \\
\hline & Total & 208 & 5,0151 & 1,17684 \\
\hline
\end{tabular}

As it is seen in Table 8, job satisfaction does not show an obvious and clear difference in terms of public and private sector corporations. According to Table 8, there is 4,5653 descriptive mean among the personals of $\mathrm{S}$, which is a public foundation. .According to this situation, the rate of $S$ is the further rate to the mean rate which is 5,0151 . So, there is not a reasonable difference between $S$ and other private sector corporations. So, our hypothesis that is developed at 0,05 mean square is accepted, too. 
Table 9: one way anova statistical results of job satisfaction

\begin{tabular}{|l|c|r|r|rr|r|}
\hline & & Sum of & df & Mean & F & Sig. \\
\hline $\begin{array}{l}\text { Job } \\
\text { Satisfaction }\end{array}$ & $\begin{array}{c}\text { Between } \\
\text { Groups }\end{array}$ & 35,838 & 3 & 11,946 & 9,715 &, 000 \\
\hline & $\begin{array}{c}\text { Within } \\
\text { Groups }\end{array}$ & 250,849 & 204 & 1,230 & & \\
\hline & Total & 286,687 & 207 & & & \\
\hline
\end{tabular}

The one way analysis that is done to measure the H3 hypothesis also proves the accuracy of the hypothesis. As it is understood from the table above (Table 9) at 0,05 mean square, organizational commitment differs according to public and private sector corporations. Because organizational commitment sig. rates in Table 9 are lower than 0,05 . So, our hypothesis that is developed at 0,05 mean square is accepted, too.

\section{Table 10: job satisfaction multiple} comparison method result of

\begin{tabular}{|l|r|r|r|l|}
\hline $\begin{array}{l}\text { Dependent } \\
\text { Variable }\end{array}$ & $\begin{array}{c}\text { (I)surveyed } \\
\text { institution }\end{array}$ & $\begin{array}{r}\text { (J)surveyed } \\
\text { institution }\end{array}$ & $\begin{array}{r}\text { Mean } \\
\text { Difference (I-J) }\end{array}$ & Sig. \\
\hline Job Satisfaction & $\mathbf{O}$ & $\mathbf{S}$ & $\mathbf{, 8 4 4 5 9}\left(^{*}\right)$ & $\mathbf{, 0 0 1}$ \\
\hline & & $\mathrm{T}$ &, 14986 &, 943 \\
\hline & & $\mathrm{C}$ &,- 10730 &, 983 \\
\hline & $\mathbf{S}$ & $\mathbf{O}$ & $\mathbf{- , 8 4 4 5 9}\left(^{*}\right)$ & $\mathbf{, 0 0 1}$ \\
\hline & & $\mathbf{T}$ & $\mathbf{- , 6 9 4 7 2}\left(^{*}\right)$ & $\mathbf{, 0 1 4}$ \\
\hline & & $\mathbf{C}$ & $\mathbf{- , 9 5 1 8 9}\left(^{*}\right)$ &, $\mathbf{0 0 1}$ \\
\hline & $\mathrm{T}$ & $\mathrm{O}$ & $\mathbf{- , 1 4 9 8 6}$ &, 943 \\
\hline & & $\mathbf{S}$ & $\mathbf{, 6 9 4 7 2}\left(^{*}\right)$ & $\mathbf{, 0 1 4}$ \\
\hline & & $\mathrm{C}$ &,- 25717 &, 827 \\
\hline & $\mathrm{C}$ & $\mathrm{O}$ &, 10730 &, 983 \\
\hline & & $\mathbf{S}$ & $\mathbf{, 9 5 1 8 9}\left(^{*}\right)$ & $\mathbf{, 0 0 1}$ \\
\hline & & $\mathrm{T}$ &, 25717 &, 827 \\
\hline
\end{tabular}

* The mean difference is significant at the .05 level.

Multiple comparison analysis is aimed to identificate that in which public and private sector corporations, job satisfaction is different. At 0,05 mean square, it is identified that job satisfaction differs between $\mathrm{O}$ and S, S and T,S and Ç. It is understood that the sig. rates of public and private sector corporations in Table 10 which are lower than 0,05 are different. So, our hypothesis that is developed at 0,05 mean square is accepted, too.

Correlation analysis is aimed to correlate the public and the private sectors difference and meaningful relation of those sectors. At least 42 and at most 97 points were taken from role conflict and role ambiguity dimension. Average of $65,28 \pm 10,80$ points were taken from this dimension. According to this score, it may be stated that employee of workplace Ç experience role conflict and role ambiguity at a moderate level in their work environment.

At least 15 and at most 63 points were taken from organizational commitment dimension. Average of $49,64 \pm 10,10$ points were taken from this dimension. According to this score, organizational commitment of participants in work environment is close to average level.

At least 7 and at most 49 points were taken from job satisfaction dimension. Average of $34,92 \pm 8,16$ points were taken from this dimension. According to this score, job satisfaction of participants in work environment is at the average level.

It was determined that role conflict and role ambiguity of employees working for workplace Ç were lower than other sectors, and results were statistically significant $(F=6,286, p<0.001)$. It was determined that organizational commitment of employees working for workplace $\mathrm{S}$ were lower than other sectors, and results were statistically significant $(\mathrm{F}=5,886, \mathrm{p}<0.001)$. It was determined that job satisfaction of employees working for workplace $\mathrm{S}$ were lower than other sectors, and results were statistically significant $(F=9,502$, $\mathrm{p}<0.001$ ).

Relationship of role conflict and role ambiguity, organizational commitment, job satisfaction dimensions with descriptive properties and work experiences of participants was researched. It was found that role conflict and role ambiguity increase as age increases $(\mathrm{R}=0.169 \mathrm{p}=0.013)$, role conflict and role ambiguity increase as working time at the workplace increase $(\mathrm{R}=0.186 \mathrm{p}=0.006)$, staff at low position in establishment experience more role conflict and role ambiguity $(\mathrm{R}=0.157 \mathrm{p}=0.002)$, and job satisfaction increases as role conflict and role ambiguity decrease $(\mathrm{R}=-0.275 \mathrm{p}=0.001)$. No relationship was determined between gender, education level, length of management experience, number of employees depending on manager who the staff is accountable to, level of

Tablo 11. The result of the multiple Linear Regression analysis of Rsum prediction

\begin{tabular}{|l|l|c|c|r|r|r|r|r|r|r|r|r|}
\hline Work place & \multicolumn{3}{|c|}{ Role conflict-role ambiguity } & \multicolumn{3}{c|}{ Organizational commitment } & \multicolumn{4}{c|}{ Job satisfaction } \\
\hline & Mean & S D & F & p & Mean & S D & F & p & Mean & S D & F & p \\
\hline O & 67,33 & 10,16 & 6,286 & $<0.001$ & 52,37 & 8,76 & 5,886 & $<0.001$ & 37,41 & 5,94 & 9,502 & $<0.001$ \\
\hline S & 66,87 & 11,56 & & & 46,54 & 11,49 & & & 31,87 & 8,92 & & \\
\hline T & 64,24 & 8,98 & & & 51,88 & 6,38 & & & 36,44 & 7,53 & & \\
\hline C & 58,10 & 8,63 & & & 52,00 & 9,14 & & & 38,50 & 6,31 & & \\
\hline
\end{tabular}


organizational commitment and role conflict and role ambiguity $(\mathrm{p}>0.05)$.

In the study, it was determined that level of organizational commitment of staff with low education level is high $(\mathrm{R}=-0.142 \mathrm{p}=0.036)$, level of organizational commitment of staff whose working time in workplace is short is higher $(R=-0.159$ $\mathrm{p}=0.019$ ), and there is a relationship between level of organizational commitment and job satisfaction of employees $(\mathrm{R}=0.668 \mathrm{p}=0.001)$. No relationship was determined between gender, age, position within establishment, length of management experience, number of employees depending on manager who the staff is accountable to and organizational commitment $(\mathrm{p}>0.05)$.

It was found that level of job satisfaction of younger employees working in organizations is higher $(\mathrm{R}=$ $0.234 \mathrm{p}=0.001$ ), level of job satisfaction of staff who work less in workplace is higher $(\mathrm{R}=-0.309 \mathrm{p}=0.001)$, personnel with shorter management experience have higher level of job satisfaction $(\mathrm{R}=-0.257 \mathrm{p}=0.001)$. No relationship was determined between gender, education level, position within establishment, number of employees depending on manager who the staff is accountable to and job satisfaction $(p>0.05)$.

Multiple Linear Regressions method is used to find the relationship between age, gender, education level, working time, position within establishment, management experience, independent variables and a random term $\varepsilon$. Rsum; $\mathrm{R}=0.246, \mathrm{R}^{2}=0.061$, $\mathrm{F}_{(6,152)}=1.635, \mathrm{p}=0.141$. No statistically significant relationship was determined between age, gender, education level, working time, position within establishment, management experience and Rsum $\left(\mathrm{R}=0.246, \mathrm{R}^{2}=0.061, \mathrm{p}=0.141\right)$.

Bsum; $R=0.293, R^{2}=0.086, F_{(6,152)}=2.370, p=0.032$. Statistically significant relationship was determined between age, gender, education level, working time, position within establishment, management experience and Bsum ( $\mathrm{R}=0.293, \mathrm{R} 2=0.09, \mathrm{p}=0.032$ ). Relevant variables together explain approximately $9 \%$ of total variance in Bsum. According to standardized regression coefficient $(\beta)$, order of relative importance of prediction variables on Bsum is as follows: position within establishment, education level, working time in workplace, age, length of time of management experience and gender. When t test result about the significance of regression coefficients was analyzed, it was determined that position within establishment and education level are statistically significant prediction on Bsum whereas other variables have no significant effect.
Tsum; $\mathrm{R}=0.448, \mathrm{R} 2=0.201, \mathrm{~F}\left(_{6,152}\right)=6.368, \mathrm{p}=0.000$. Statistically significant relationship was determined between age, gender, education level, working time, position within establishment, management experience and Tsum $(\mathrm{R}=0.448, \mathrm{R} 2=0.201, \mathrm{p}<0.01)$. Relevant variables together explain approximately $20 \%$ of total variance in Bsum. According to standardized regression coefficient $(\beta)$, order of relative importance of prediction variables on Tsum is as follows: working time in workplace, position within establishment, age, education level, gender and length of time of management experience. When $t$ test result about the significance of regression coefficients was analyzed, it was determined that position within establishment and working time in workplace are statistically significant prediction on Tsum while other variables have no significant effect.

\section{RESULTS AND SUGGESTIONS}

In this study, the perceptions of role conflict, role ambiguity and job satisfaction, and organizational commitment of employees in both public and private sectors are studied. Data were gathered from two organizations in the public sector and two organizations in the private sector in region of the east Mediterranean, included Adana, Mersin, Osmaniye, Hatay, province of Turkey. Three hypothesizes were supported by the one-way ANOVA analysis, which were done to test the study's hypotheses. This means that, as posited by the study's hypotheses, the level of role conflict and role ambiguity with job satisfaction and organizational commitment has perceived in a different way for public and private sector. In other words, the more a worker perceives role conflict, role ambiguity, job satisfaction and organizational commitment in public sectors the less the private sectors workers will feel opposite. In the search for increasing organizational performance and effectiveness, today's organizations must pay particular importance to their employees' job satisfaction and organizational commitment in order to reach organizational aims. The results of this study show that the organization's managers and human resource professionals must address problems caused by role conflict and role ambiguity. In this context, we can point to improving organizational communication to decrease role conflict and role ambiguity. In addition, priority has to be given to the problems occurring during the establishment of an organization including position, responsibility and role identification and delegation of authority.

All empirical studies have specific restrictions. First among these limitations is caused by gathering data 
through a questionnaire. Answering questions in the questionnaire or providing explanations in a short time frame turns the method variant into a potential constriction. Using a questionnaire in this study was defined as the natural method for data gathering as this study focused on participants' perceptions. Thus, stronger studies should be carried out using panel data. Future studies on this subject can be improved by adding more participants and different working groups. Likewise, using different scales developed differently from the scales used in this study, will allow researchers to better understand the relationship between role conflict and role ambiguity on employees' manners.

\section{APPENDIX 1}

Questionnaire Form

Gender

Age

Education

Position within establishment

Length of management experience

The number of employees depending on manager

\section{Job satisfaction items}

1. I am satisfied with the persons in my work group.

2. I am satisfied with my supervisor.

3. I am satisfied with my job

4. I am satisfied with this organization, compared the most.

5. I am satisfied with my pay, considering my skills and effort I put into my work.

6. I am satisfied with the progress I have made in this organization up to now.

7. I am satisfied with my chance for getting ahead in this organization in the future.

\section{Organizational Commitment items}

1. I am willing to put in a great deal of effort beyond that normally expected in order $t$ help this organization be successful

2. I talk up this organization to my friends as a great organization to work for

3. I would accept almost any types of job assignment in order to keep working for this organization

4. I find that my values and the organization's values are very similar

5. I am proud to tell others that I am part of this organization
6. This organization really inspires the very best in me in the way of job performance

7. I extremely glad that I chose this organization to work for over others I was considering at the I joined

8. I really care about the fate of this organization

9. For me, this is the best of all possible organizations for which to work

Role conflict and Role ambiguity items

1. I have to do things that should be done differently

2. I have to buck a rule of a policy in order to carry out an assignment

3. I receive incompatible requests from two or more people

4. I do things that are apt to be accepted by one person and not accepted by others

5. I work on unnecessary things

6. I work with two or more groups who operate quite differently

7. I receive assignments without the manpower to complete them

8. I receive assignment without adequate resources and material to execute them

9. I know exactly what is expected of me $(\mathrm{R}=$ Reversed $)$

10. I know that I have divided my time properly(R)

11. Explanation is clear of what has to be done( $R)$

12. I feel certain about how much authority I have(R)

13. I know what my responsibilities are (R)

14. Clear, planned goals and objectives exist for my job (R) 


\section{REFERENCES}

Acker, G.M. (2004), The effect of organizational conditions (Role Conflict, Role Ambiguity, Opportunities for Professional Development and Social Support) on job satisfaction and intention to leave among social workers in mental health care, Community Mental Health Journal, 40(1), pp. 5-73.

AL-Aameri, A.S., 2000. Job satisfaction and organizational commitment for nurses. Saudi Medical Journal 21 (6), 531 - 535.

Aryee, S., Luk, V., \&Stone, R.(1998). Family responsive variables and retention-relevant outcomes among employed parents. Human Relations, 51(1), 72-89.

Babakus, E., Cravens, D.W. and Moncrief, W.C. (1996), Examining the role of organizational variables in the salesperson job satisfaction model, Journal of Personal Sales Management, 16(3), pp. 33-46.

Babakus, E., Cravens, D.W. and Moncrief, W.C. (1999), The role of emotional exhaustion in sales force attitude and behavior relationships, Journal of Academic Marketing Science, 27(1), pp. 58-70.

Babin, B.J. and Boles, J.S. (1998), Employee behavior in a service environment: A model and test of potential differences between men and women, Journal of Marketing Mark, 62, pp. 77-91.

Becker, T. E., (1992) Billings, R.S., Eveleth, D.M., \& Gilbert, N. L.(1996). Foci and bases of employee commitmet: Implications for job performance.

Academy of management journal, 39(2), 464-482

Brown, S.P. and Peterson, R.A. (1993), Antecedents and consequences of salesperson jobsatisfaction: meta -analysis and assesment of causal effects, Journal of Marketing Resources, 30, pp. 63-67.

Ceylan, A. and Ulutürk, Y.H. (2006), Rol belirsizliği, rol çatışması iş tatmini ve performans arasındaki ilişkiler, Doğuş Üniversitesi Dergisi, 7(1), pp. 48-58.

Churchill, G.A. Jr., (1999), Marketing Research: Methodological Foundation, 7th Edition, Forth Worth: The Dryden Pres.

Cohen A. (1995). An examination of relationships between work commitment and non-work domains. Human Relations, 48(3), 239-263

Cohen A. (1996). On the discriminant validity of the Meyer and Allen measure of organizational commitment: how does it fit with the work commitment construct? Educational and psychological measurement, 56(3), 494-503
DeConinck, J.B. and Stilwell, C.D. (2004), Incorporating organizational justice, role states, pay satisfaction and supervisor satisfaction in a model of turnover intentions, Journal of Business Research, 57, pp. 225-231.

Draper, J., Halliday, D., Jowett, S., et al., 2004. NHS Cadet Schemes: student experience, commitment, job satisfaction and job stress. Nurse Education Today 24 (3), 219-228.

Dulebohn, J. H., \& Martocchio, J.J. (1998). Employee perceptions of the fairness of work group incentive pay plans. Journal of Management, 24(4), 469-488

Grant, K., Cravens, D.W., Low, G.S. ve Moncrief, W.C. (2001), The role of satisfaction with territory design on the motivation, attitudes, and work outcome of salespeople, Journal of Academic Marketing Science, 29(2),pp. 65-78.

Greene, C. (1978), Identification modes of professionals: Relationship with formalization, role strain and alienation. Academy of Management Journal 21, 486-492.

Harris, E.G., Artis, A.B., Walters, J.H. and Licata, J.W. (2006), Role stressors, service workers job resourcefulness, and job outcomes: An empirical nalysis, Journal of Business Research, 59, pp. 407 415.

Huselid, M. A., \&Day, N. E. (1991). Organizational commitment, job involvement, and turnover: A substantive and methodological analysis. Journal of Applied Sociology, 76(3), 380-391

Jackson, S.E., and Schuler, R.S. (1985), A metaanalysis and conceptual critique of research on role conflict and role ambiguity in work settings, Organizational Behavior and Human Decision Process, 36(1), pp. 16-78.

Jamal, M. (1990), Relationship of job stress and TypeA behaviour to employees' job satisfaction, organizational commitment, psychosomatic health problems and turnover motivation, Human Relations, 43(8), pp. 727-738.

Jones F. F., Scarpello, V., \& Bergmann, T. (1999). Pay procedures-What makes them fair? Journal of Occupational \& Organizational Psychology, 72(2), 129-145

Kahn, R., Wolf, D., Quinn, R., Snoek, J., \& Rosenthal, R. (1964). Organizational stress: Studies in role conflict and ambiguity. New York: Wiley.

Katz, D., \& Kahn, R. (1978). The social psychologyof organizations. New York: Wiley. 
Keenan, A. and McBain, G. D. M. (1979), Effects of Type A-behaviour, intolerance of ambiquity, and locus of control on the relationship between role stress and work-related outcomes, Journal of Occupational Psychology, 52(A): 277.

Kemery, E., Mossholder, K., \& Bedeian, A. (1987). Role stress, physical symptomology, and turnover intentions: A causal analysis of three alternative specifications. Journal of Organizational Behavior, 8, 11-23.

Kirchmeyer, C. (1992). Non-work participation and work attitudes: A test of scarcity vs. expansion models of person personal resources, Human Relations, 45(8), 775-795.

Lankau, M., Carlson, D.S. and Nielson, T.R. (2006), The mediating influence of role stressors in the relationship between mentoring and job attitudes, Journal of Vocational Behavior, 68, pp. 308-322.

Mathieu, J E., \& Farr, J. L., (1991). Further evidence for the discriminant validity of measures of organizational commitment, job involvement and job satisfaction. Journal of Applied Psychology, 76(1), 127-133

Miles, R. (1976). Role Requirements As Sources Of Organizational Stress. Journal of Applied

Psychology,61 (2), 172-179.

Mowday, R.T., Steers, R.M., Porter, L.M., 1979. The measurement of organizational commitment. Journal of Vocational Behavior 14, 224-227.

Mowday, Rt., Porter, L.W. and Steers, R.M. (1982), Employee-organization linkages: The psychology of commitment, absenteeism, and turnover,New York: Academic Pres.

Namasivayam, K. and Zhao, Xinyuan. (2007). An investigation of the moderating effects of organizational commitmet on the relationships between work-family conflict and job satisfaction among hospitality employees in India, Tourism Management, 28(5), pp. 1212-1223.

Redfern, S., Hannan, S., Norman, I., 2002. Work satisfaction, stress, quality of care and morale of older people in a nursing home. Health and Social Care in the Community 10 (6), 512-517.

Rizzo, J. R., House, R. J. and Lirtzman, S. I. (1970), Role conflict and ambiquity in complex organizations, Administrative Sciences Quarterly, 15, 150-163.

Schaubroeck, J., Ganster, D., Sime, W. and Ditman, D. (1993), A field experiment testing supervisor role clarification, Personel Psychology, 46, pp. 1-20.
Somers, M. J., \&Casal, J. C. (1994). Organizational commitment and whistle-blowing: A test of the reformer and the organization man hypothesis. Group \& Organization Management, 19(3), 270-285.

Taylor, J.S. and Bowers, D.G. (1974), the survey of organizations: Towards a machine scored, standardized questionnaire, Ann Arbor: University of Michigan, Institute for Social Research.

Thompson. H. B., \& Werner, J. M. (1997). The impact of role conflict/facilitation on core and discretionary behaviors: Testing a mediated model. Journal of Management, 23(4), 583-602.

Tuten, T.L. and Neidermeyer, P.E. (2004), Performance, satisfaction and turnover in call centers: The effects of stres and optimism, Journal of Business Research, 57, pp. 26-34.

Wahn. J. C. (1998). Sex differences in the continuance component of organizational commitment. Group \& Organization Management, 23(3), 256-267.

Warr, P., Cook, J., Wall, T., 1979. Scales for the measurement of come work attitudes and aspects of psychological wellbeing, Journal of Occupational Psychology 52, 129-148.

Wayne, S. J., Shore, L. M., \& Liden, R. C. (1997). Perceived organizational support and leader-member exchange: A social exchange perspective. Academy of Management Journal, 40(1), 82-111

Weatherly, K.A. and Tansik, D.A. (1993), Tactics used by customer-contract workers: ffects of role stres, boundary spanning and control, International Journal of Services Industries Management, 4(3), pp. 4-17.

Yousef, D.A. (2000), The interactive effects of role conflict and role ambiguity on job satisfaction an attitudes toward organizational change: A moderated multiple regression approacah, International Journal of Stres Management, 7(4), pp. 289-3003. 